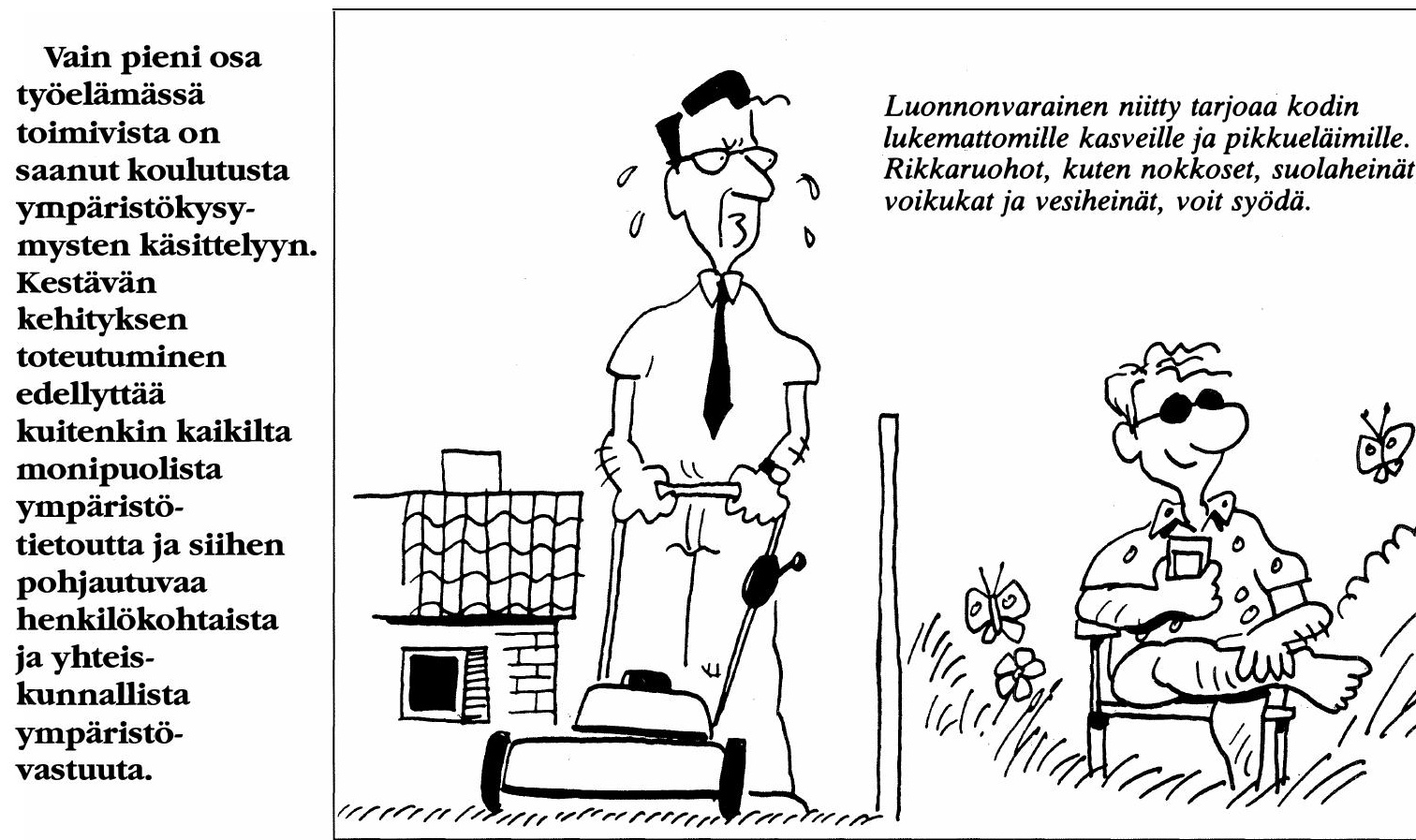

Suomen Kirkon Seurakuntatoiminnan Keskusliiton ja Kristillisen Opintokeskuksen Sanoista tekoihin -ympäristökasvatuskampanjan korttisarjaa.

\title{
Ympäristökasvatuksen haasteet, näkymät ja tehtävät aikuiskoulutuksessa
}

Ihminen on käyttänyt luonnonvaroja ja muuttanut luonnonympäristöä omiin päämääriinsä soveltuvaksi uskoen, että luonto on ihmisen arvoja ja tarpeita varten. Ihminen on kokenut itsensä luonnon käyttäjäksi, ei sen osaksi, ja on pyrkinyt pois luonnon armoilta muuttamalla sitä. Käsitys luonnosta rajattomasti hyödynnettävänä resurssina on kuitenkin osoittautunut kestämättömäksi ja vaaralliseksi. Maapallon ekosysteemien muuttaminen ei ole tehnyt ihmisestä luonnonjärjestelmien hal-litsijaa, olemme edelleen luonnon armoilla (Willamo 1992). Nyt yritämme luoda strategiaa kestävälle kehityk- selle, jolla tähdätään ekologisen tasapainon palauttamiseen. Se edellyttää syvällistä luonnonvarojen käyttötapojen ja kulutustottumusten uudelleen arviointia. Ihmisen on opittava toimimaan tietoisena luonnon reunaehdoista ja tulevien sukupolvien oikeuksista elinkelpoiseen ympäristöön.

Tiedotus ympäristön tilan muutoksista ja ympäristökatastrofeista sekä ympäristökasvatus ovat lisänneet yleistä ympäristötietoutta. Tieto on saanut monet huolestuneiksi ja halutaan, että asiantuntijat ryhtyvät toimenpiteisiin tilan- 
teen korjaamiseksi. Monet ovat valmiita osallistumaan ympäristöinvestointien kustannuksiin, mutta vain pieni vähemmistö on muuttanut omaa käyttäytymistään. Tiedon lisääntyminen ei ole johtanut käyttäytymisen muuttumiseen, omat edut ja mukavuus näyttävät painavan enemmän kuin periaatteet (Uusitalo 1986). Pyrkimys kohti kestävää kehitystä edellyttää myös uutta panostusta ja ajattelua ympäristökasvatuksessa.

\section{Ympäristön tila ja siitä nousevat haasteet ympäristökasvatukselle}

Ihmiskunnan kehitystä on tähän asti voitu kuvata vain ylöspäin kohoavilla käyrillä; kaikkea on nyt enemmän kuin ennen, kaikki tapahtuu nopeammin kuin koskaan. Maapallolla ei ole milloinkaan ollut niin paljon ihmisiä kuin nyt ja koskaan ei ole kulutettu yhtä paljon kuin nykyään (Ympäristön tila Suomessa 1992).

Maapallon väestönkasvu on edelleen rajua: ihmiskunta kasvaa lähes sadalla miljoonalla joka vuosi. Henkeä kohden laskettu maataloustuotanto on kääntynyt laskuun tehostuneesta tuotantotavasta huolimatta. Peltopinta-ala pienenee aavikoitumisen, rakentamisen ja eroosion takia eikä uusia viljelykelpoisia alueita enää juurikaan ole hyödyntämättä. Tarve yhä tehokkaampaan tuotantoon kasvaa ja kilpailu elintarvikkeista kiihtyy. Joka kolmas lapsi kärsii aliravitsemuksesta ja yli miljardilta ihmiseltä puuttuu juomakelpoinen vesi (Worldwatch-instituutin raportit 1991 ja 1992).

Kasvavan tuotannon ja kulutuksen ympäristörasitukset näkyvät ympäristön sietokyvyn ylityksinä ilmassa, vedessä ja maaperässä sekä eliökunnassa. Vaikka yksittäisten tuotantolaitosten ympäristökuormitusta on saatu kehittyneissä maissa pienemmäksi ja vaikka tiettyjen haitallisiksi todettujen kemikaalien osalta on saatu huomattavia päästövähennyksiä aikaiseksi, epäedulliset muutokset jatkuvat. Yli puoli miljardia ihmistä asuu pahoin saastuneilla alueilla. Olemme ajautumassa maailmanlaajuiseen kehitys-, talous- ja ympäristökriisiin (Worldwatch-instituutin raportit 1991 ja 1992).
Maapallon elinkelpoisuuden säilyttäminen tulee vaatimaan voimakasta panostusta sekä ennalta ehkäisevään että jo syntyneitä vaurioita korjaavaan ympäristönsuojeluun. Luonnontaloudellisesti kestäviin tuotanto- ja kulutustapoihin pääseminen edellyttää uuden tietoisuuden kehittymistä; tietoisuuden, joka johtaa ymmärrykseen, sitoutumiseen ja toimintatapojen muuttamiseen. Ympäristökasvatus on oleellinen osa ympäristönsuojelua.

\section{Ympäristökasvatuksen asema aikuiskoulutuksessa}

Aikuisten ammatillisessa peruskoulutuksessa ympäristökasvatuksen osuus on yleensä vaatimaton. On aloja, joilla ei ainakaan opetussuunnitelmien perusteiden mukaan ympäristökysymyksiä käsitellä lainkaan. Joillakin aloilla ympäristön käyttöön ja suojeluun sekä haitallisten ympäristövaikutusten hoitoon ja seurantaan liittyviä aiheita käsitellään ammattiaineiden yhteydessä. Ympäristökysymysten painoarvo ja käsittelytapa ovat riippuvaisia oppilaitosten ja yksittäisten opettajien tiedoista ja asenteista.

Ympäristökysymyksiin perehtyneiden henkilöiden kysyntä mm. teollisuudessa ja hallinnossa on lisääntynyt voimakkaasti. Ammatilliseen peruskoulutukseen on suunniteltu joitakin uusia, ympäristöalan ammatteihin kouluttavia linjoja. Esimerkiksi insinööritutkinnon voi suorittaa ympäristö- ja terveystekniikan alalta. Viime vuosina on kehitelty eri alojen ammattilaisille puolen vuoden kestoisia ympäristöalan jatkolinjoja, joilla voi perehtyä oman alan keskeisiin ympäristökysymyksiin. Syksyllä 1992 toteutettiin kymmenkunta ympäristöalan jatkolinjaa.

Kansalaisopistoissa ja kansanopistoissa on järjestetty ympäristöalan yleisluentoja tai lyhyitä kursseja. Kurssien teemat ovat olleet useimmiten käytännönläheisiä, esimerkiksi kierrätykseen tai kuluttajakasvatukseen liittyviä, mutta joukossa on ollut myös luentoja esimerkiksi ekologian perusteista. Vapaan sivistystyön oppilaitoksissa on annettu myös avointa korkeakouluopetusta. Avoimessa korkeakouluopetuksessa 
aikuisopiskelijat voivat suorittaa yliopistojen perusopetukseen rinnastettavan ympäristöalan 15 ja 35 opintoviikon opintokokonaisuuden tai osia niistä. Järjestävästä yliopistosta riippuen opetus painottuu eri aihepiireihin. Kaikissa johtavana teemana on kuitenkin ihmisen toiminnan ja luonnonvarojen käytön arvioiminen luonnontalouden kestävyyden näkökulmasta. Kiinnostus ympäristöalan yliopistollisten arvosanojen suorittamiseen on lisääntynyt voimakkaasti.

Iltalukiossa ympäristönsuojeluun liittyviä kysymyksiä käsitellään eri oppiaineiden yhteydessä läpäisyperiaatteella. Biologian ja maantieteen oppisisällöissä on eniten ympäristökasvatukseen liittyvää ainesta. Joissakin iltalukiossa on järjestetty koulukohtaisia kursseja ajankohtaisista ja paikallisesti tärkeistä ympäristökysymyksistä.

Monet yliopistojen ja korkeakoulujen täydennyskoulutuskeskukset, jotkut ammatilliset aikuiskoulutuskeskukset sekä erilaiset järjestöt ja yhdistykset järjestävät eri alojen ammattilaisille ympäristöalan täydennyskoulutuskursseja. Mm. Lahden tutkimus- ja koulutuskeskus on keskittynyt ympäristöalan täydennyskoulutukseen.

Opettajien peruskoulutuksessa ympäristökysymysten käsittely on yleensä hajanaista ja sattumanvaraista. Täydennyskoulutustarjontaa sen sijaan on runsaasti, mutta koulutukseen osallistumismahdollisuudet vaihtelevat. Jotkut opettajat ovat ryhtyneet suorittamaan myös yliopistollisia arvosanoja ympäristöalalta.

Vain pieni osa aikuisväestöstä on perehtynyt ympäristökysymyksiin koulutuksessa. Suurin osa on muodostanut käsityksensä ympäristön tilasta ja sen edellyttämistä muutostarpeista tiedotusvälineiden antaman informaation ja oman kokemuksensa perusteella.

\section{Ympäristökasvatuksen näkymät}

Eduskunnan ja valtioneuvoston osoittama poliittinen tahto ja viranomaisten vahva tuki ovat nostamassa ympäristökasvatusta suomalaisessa koulutuspolitiikassa uuteen asemaan. Kestävän kehityksen periaatteiden opiskelu halutaan mukaan kaikkeen koulutustoimintaan. Ympäristökasvatukseen sitoutumisen esteitä on kuitenkin edelleen runsaasti. Asenteiden ja käytäntöjen muutos ei ole helppoa.

Tutkintotavoitteisen aikuiskoulutuksen opetussuunnitelmien valtakunnallisten perusteiden uudistamistyö on käynnissä sekä ammatillisen että yleissivistävän koulutuksen osalta. Ammatinhallintaan ja myös elämän hallintaan liittyviä aihekokonaisuuksia arvioidaan uudelleen. Ympäristökysymysten mukaan otto on tässä vaiheessa mahdollista uudella tavalla.

Ammatillisessa koulutuksessa uudistustyöhön ryhdyttiin pari vuotta sitten, jolloin nimettiin 13 ympäristökasvatuksen kehittämisoppilaitosta ja lisäksi kullekin tueksi 1-5 muuta oman alan oppilaitosta. Kehittämisoppilaitosten tehtävänä on ollut analysoida alansa opetussuunnitelmien perusteet ympäristökasvatuksen näkökulmasta ja tehdä uudistamisesityksiä. Tehtävänä on myös opettajien ja muun oppilaitoshenkilökunnan ympäristökasvatuksen lisäkoulutuksen suunnittelu ja järjestäminen, oppimateriaalien kartoittaminen sekä yhteyksien luominen ja kehittäminen elinkeinoelämään. Ympäristöprojektin lopullisena tavoitteena voidaan pitää kestävän kehityksen periaatteiden huomioimista kaikessa opetuksessa sekä koko oppilaitoksen toiminnassa. Kehittämisoppilaitosten työn tuloksia käytetään opetussuunnitelmien perusteita uudistettaessa.

Ympäristönsuojelu on sekä kansallista että kansainvälistä toimintaa. Jotkut ammatilliset oppilaitokset ovat mukana myös kansainvälisissä ympäristökasvatushankkeissa. "LCA and Eco Design Education Program"- hankkeen yhteydessä luodaan kurssiohjelmia ja materiaaleja tuotteiden elinkaarianalyysien eli ekotaselaskelmien opetukseen. Ammatillisia oppilaitoksia on mukana myös Unescon Itämeri-projektissa ja OECD/CERI:n Environment and School Initiatives -projektissa.

Vaikka edellä mainitut ympäristökasvatusprojektit koskevat enimmäkseen nuorisokoulutusta, sieltä saadaan aineistoa myös aikuiskoulutuksen uudistamiseen. Yksinomaan aikuiskou- 
lutusta koskevia kehittämishankkeita on myös käynnistetty. Kaapro - kemian aikuisopetuksen kehittämisprojekti alkoi 1991 opetushallituksen toimesta 13 koti- ja laitostalouden, terveydenhuollon ja tekniikan alan oppilaitoksessa. Ympäristönsuojelu on hankkeessa läpäisevänä teemana. Ympäristöystävällinen oppilaitos-projekti käynnistyi viime vuonna Ammatti-Instituutissa Helsingissä. Tavoitteena on kehittää sekä kouluympäristöä että opetussisältöjä kestävän kehityksen näkökulmasta.

Iltalukioiden uudistuvissa opetussuunnitelmien perusteissa ympäristökasvatuksen asema vahvistuu. Ympäristönäkökulma on entistä voimakkaammin mukana eri oppiaineissa ja ympäristökysymysten käsittelyyn tullee omia kursseja. Myös muu yleissivistävä aikuiskoulutus tarjoaa ympäristöalan koulutusohjelmia entistä enemmän, sillä ainakin tähän asti kysyntä on ollut kasvussa.

Ympäristöalan ammatillinen täydennyskoulutustarjonta lisääntyi 1980-luvun lopulla voimakkaasti. Lama karsii kurssien määrää ja toivottavasti nostaa laatua kilpailun kurssilaista koventuessa.

\section{Ympäristökasvatuksen tehtävät}

Ympäristökasvatuksen tehtävä on kestävän kehityksen edistäminen. Luonnontaloudellisesti kestäviin tuotanto-, kulutus- ja elintapoihin pääseminen edellyttää tietojen, taitojen, asenteiden ja arvojen määrätietoista kehittämistä ja kokonaisvaltaista ajattelua. Koulutustoiminnan tulisi luoda oppimisympäristöjä, joissa syntyy sellaisia kestävän kehityksen strategioita, joihin opiskelijat ovat valmiita sitoutumaan. Päämääränä on ympäristövastuu, joka ilmenee erilaisten toimien ympäristövaikutusten arviointitaidoissa ja siihen pohjautuvissa elämäntavan muutoksissa sekä yhteiskunnallisessa toiminnassa.

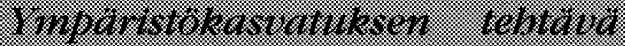

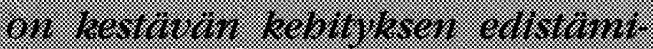
1.
Aikuisväestön koulutustarve voidaan jakaa karkeasti kahteen osa-alueeseen. Toisaalta tarvitaan perustietojen täydentämistä luonnon toimintojen ja niissä ilmenevien häiriöiden ymmärtämiseksi, teknologian mahdollisuuksien ja rajoitusten ymmärtämiseksi sekä taloudellisten ja yhteiskunnallisten mahdollisuuksien ymmärtämiseksi. Toisaalta tulisi oppia arvioimaan oman työtehtävän ja elämäntavan ympäristövaikutukset ja haitallisten vaikutusten vähentämismahdollisuudet.

Ympäristövastuu herää usein ihmisen omaan hyvinvointiin kohdistuvista uhista; likaisen ilman hengittäminen, erilaisten ruokaan tai juomaveteen kulkeutuneiden yhdisteiden "pakkosyönti" , asuinympäristön elollisen luonnon tilan näkyvä heikentyminen jne saavat oivaltamaan oman terveyden riippuvuuden ilman, veden, maaperän ja muiden eliökunnan lajien tilasta. Oman ekologisen paikkansa oivaltaminen, omien ja yhteisönsä tekemisten seurausten ymmärtäminen saa etsimään vaihtoehtoisia toimintamalleja. Aikuisten ympäristökasvatuksen tulisi olla ympäristön lukutaitoon harjaantumista, tiedon etsimistä, aikaisempien käsitysten kriittistä tarkastelua ja kokemusten tulkintaa. Kokemuksellinen oppiminen ja ongelmaratkaisutaitojen kehittäminen ovat oleellisia. Ympäristövastuullisen ihmisen on kyettävä jatkuvaan kriittiseen reflektioon (Wahlström 1991).

Yleissivistävän aikuiskoulutuksen tehtävä on ympäristökysymysten ymmärtämiseen tarvittavien ekologisten, taloudellisten, teknisten, eettisten, esteettisten ja sosiaalisten perustietojen täydentäminen, sillä aikuisten varhaisempi koulutus on sisältänyt niitä niukasti. On tärkeää oppia hakemaan ympäristöä koskevia tietoja, käsittelemään ja soveltamaan niitä. Pyrkimys kokonaisuuksien hahmottamiseen ja riippuvuussuhteiden ymmärtämiseen on oleellista. Tavoitteena on sellaisten valmiuksien saavuttaminen, jolloin opiskelija ei vain ajattele, vaan myös toimii elämää suojelevien arvojen ja asenteiden perustalta.

Ammatillisen peruskoulutuksen aikana opiskelijoille tulisi selvitä oman alan koko tuotantoprosessin aiheuttama ympäristön kuormitus seurausvaikutuksineen. Heidän tulisi harjaantua kehittämään vaihtoehtoisia toimintatapoja hai- 
tallisten ympäristövaikutusten minimoimiseksi sekä normaali- että vahinkotilanteissa. Ympäristönsuojelullisesti oleellisia asioita ovat pyrkimys suljettuihin kiertoihin, materiaalin ja energian tehokkaaseen käyttöön ja päästöjen puhdistukseen. Ammattiosaamiseen kuuluu alan ympäristövastuu.

Monilla aloilla tarvitaan ympäristökysymyksiin erikoistuneita asiantuntijoita, joiden koulutukseen tulisi suunnitella jatkolinjoja tai muuta pidempikestoista ammatillista täydennyskoulutusta.

\section{Esimerkkejä ympäristönäkökulman sisällyttämisestä oppisisältöihin}

Kaikkien alojen opetussuunnitelmiin tulisi sisällyttää myös ympäristönäkökulma. Ammattitaitovaatimusten tarkistaminen voisi tapahtua esimerkiksi seuraavasti.

Rakennusalan erilaisiin ammatteihin kouluttautuvien opinto-ohjelmiin kuuluu erittäin niukasti tai ei ollenkaan ympäristökysymysten käsittelyä. Kuitenkin rakennusalan henkilöstöllä on suuri ympäristövastuu, joka tulisi näkyä ammattitaitovaatimuksissa. Yhdyskuntarakenne on ympäristöongelmien luoja tai lievittäjä: jos työpaikat, palvelut ja harrastusympäristöt sijaitsevat kaukana toisistaan, seurauksena on kalliit materiaalia ja energiaa kuluttavat ratkaisut yhteyksien luomisessa ja käyttämisessä. Yhdyskuntarakenteen suunnittelijalla tulisi olla valmiuksia ennakoida erilaisten ratkaisujen ympäristövaikutuksia. Jokainen rakennus muuttaa ympäristönsä ekologisia, taloudellisia, sosiaalisia ja esteettisiä ominaisuuksia. Rakentajan tulisi tehdä ratkaisuja tietäen rakennuksen ympäristövaikutukset. Rakennussuunnittelussa tehdään runsaasti ympäristöön ja terveyteen liittyviä ratkaisuja: materiaalien valinta, lämmitys- ja tuuletusjärjestelmien valinta, jätehuoltoratkaisut jne. Rakennustoiminnan aikana vaikutetaan ympäristön tilaan. Vaarallisten aineiden käsittelyn ja varastoinnin järjestäminen, jätteiden ja maamassojen käsittely, melukysymysten ratkaisut, puiden suojaus jne näkyvät ympäristössä sekä rakennustyön aikana että myöhemmin.
Hotelli- ja ravitsemusalalla tehdään suuria hankintoja, joihin liittyvillä ratkaisuilla on monia ympäristövaikutuksia. Hankittavien tarvikkeiden koko elinkaaren ympäristö- ja terveysvaikutukset tulisi olla tiedossa ratkaisutilanteissa. Tavarahankintojen lisäksi pesuainevalinnoilla, jätteiden hyötykäytön tehostamisella, huoneiden lämpötilan säätelyllä jne voidaan vaikuttaa ympäristön kuormitukseen. Myös hotelli- ja ravitsemusalan rakennukset kaikkine piharatkaisuineen ovat oleellinen tekijä miljöössä sosiaaliselta, esteettiseltä ja ekologiselta kannalta. Alan ammattitaitovaatimuksia määriteltäessä mm. edellä mainitut alan ympäristövastuuseen liittyvät aihekokonaisuudet tulisi olla mukana.

\section{LÄHTEET}

Maailman tila 1991. Worldwatch-instituutin raportti.

Maailman tila 1992. Worldwatch-instituutin raportti.

Uusitalo Liisa. 1986. Suomalaiset ja ympäristötutkimus taloudellisen käyttäytymisen rationaalisuudesta. Helsingin kauppakorkeakoulu A:47.

Wahlström Riitta. 1992. Ympäristövastuun opetus korkeakoulutuksen haasteena. Teoksessa Ojasta allikkoon? toim. Outi Kinttula ja Tarja Parviainen. Suomen Ylioppilaskuntien liitto ry. SYL-julkaisu 3/92.

Willamo Risto. 1992. Pirstaleisen inmisen pirstaleinen ympäristökoulutus. Teoksessa Ojasta allikkoon ? toim. Outi Kinttula ja Tarja Parviainen. Suomen Ylioppilaskuntien liitto ry. SYL-julkaisu 3/92.

Ympäristön tila Suomessa. 1992. Vesi- ja ympäristöhallitus, ympäristötietokeskus. Toim. Erik Wahlström, Tapio Reinikainen, Eeva-Liisa Hallanaro. 